\title{
KING JOHN OF FRANCE AND THE ENGLISH SPICERS
}

\author{
by \\ LESLIE G. MATTHEWS
}

Worth a King's ransom! A handsome sum, the three million écus d'or demanded as ransom for King Jean II (le Bon) of France under the terms of the Treaty of Brétigny, I36r. John, captured by the Black Prince at Mapertuis near Poitiers, was brought from Bordeaux to England on 24 May 1357. With him came a personal retinue of forty or more, including his chief servants, his physician, his apothecary or spicer, and-no less important for the royal party than for history-Denys de Collors 'chapellain et notaire dudit Seigneur', who acted as Chancellor-Treasurer for the royal household during the whole period. Brétigny, called by the French 'le Traité humiliant' and 'la désastreuse paix' was an attempt to relieve both England and France of continuous conflict when the King had already been a prisoner in England for three years.

Denys de Collors, a canon of the Sainte Chapelle in Paris, was a trusted servant. His accounts for the first two years of the King's captivity are no longer available, lost perhaps because of changes in ownership or location, at least there is a hint of this in Douet-d'Arcq's Comptes de l'Argenterie* but he fortunately was able to identify and transcribe the accounts for the third year; I July I 359 to 8 July I 360 , when John was ready to leave for France.

Bursars' accounts for French kings were no new form of record as the appointment of Geoffroi de Fleuri by King Philippe in $1317 \dagger$ and his successors show. It was important that both income and expenditure (dépenses) should be recorded accurately. This de Collors did to the best of his ability and the information supplied to him.

During the year for which we have the accounts King John (with whom was his favourite son 'Monseigneur Philippe, better known as 'le Hardi', duc de Bourgoyne, afterwards King Philippe II) was first moved from the Palace of Savoy, London, to Hertford Castle-there had been rumours of plots and rescues-and thence, under the guardianship of William, Baron d'Eyncourt, to Somerton Castle, near Navenby, Lincs. on 29 July 1359.

While a prisoner in England, the King had his own means of providing for himself and his establishment. He was supplied with funds by devious routes and in varied currencies from vassals, supporters or well-wishers. The sources of these are not always given, merely the mention of a sum, of which de Collors records an acknowledgment: 'J'ai rendu compte de toute ceste recepte'.

* Douet-d'Arcq., L. Comptes de l'Argenterie des Rois de France au XIVe siecle, Paris, Chez Jules Renouard et Cie, 1851, 432 pp. Dr. Charles Talbot, Research Scholar at The Wellcome Historical Medical Museum, London, drew my attention to these accounts as a source of information on medieval English spices, and to him I am indebted for friendly help and criticism of this paper.

† Ibid., p. 4. $\$$ Ibid., p. 196 . 


\section{Leslie G. Matthews}

To the medical and pharmaceutical historian the major interest of the year's accounts is the quantity and variety of spices and medicines that were needed to sustain the King and his entourage during a few months, and the occasional references to medical or veterinary treatment. The accounts are valuable in showing the wide range of spices and drugs available in England in the middle of the fourteenth century as well as prices then current in Lincoln, Boston and London.

Among his sources of revenue while at Somerton, John derived monies from the sale of surplus wine, which with many of his other provisions came in through the port of Boston, referred to in these accounts as 'St Boutoul'.*

From time to time it is a spicer (or apothecary) of St. Boutoul, Jehan Kelleshulle (the name is variously spelt-see Appendix II), who either buys some of this surplus wine for his own needs-he pays for ' 4 tonneaux de vin, 4 mars et demi pour tonneau, valent 36 nobles, qui valent $£ 12$ ' (sterling), $\dagger$ or with G. Spaigne (see Appendix II), is charged with the duty of examining the Royal stock of wine and reporting on its keeping quality. This happened when the King was in London just prior to his departure for France, as shown by an entry 2 June 1360 , 'pour savoir l'estat des vins du Roy qui y estoient demourez de la garnison du Roy'. $\ddagger$

This year's accounts, the details of which were written in medieval French, and so transcribed $\S$ were kept in English $£$. s. d. and de Collors must have been at pains to work in an unaccustomed currency. His receipts, and some of his payments, were in écus, moutons d'or, nobles, marks, French livres, sous and deniers, petiz florins de Florence, as well as $f$. s. d.

The vast quantities of drugs and spices, particularly, were in keeping with the hearty needs of the time and with the French royal family custom. Over the previous century or so sweetmeats or comfits and dragées (of the sugared almond type) had become an essential dessert, either as 'digestives' or as supplements to an otherwise plain diet of roast or boiled meat or fish. The habit was widespread and continued into the seventeenth century at least. Marlowe in The Tragedy of Dido, Queen of Carthage, Act II (i), wrote: 'I'll give thee sugar almonds, sweet conserves', and in the compilation of the First London Pharmacopoeia $(16,8)$ the task of classifying the Tragemata-'desserts supporting digestion'-was assigned to the Royal Physicians: the Tragemata represented

\footnotetext{
* Boston, mentioned in many early records as St. Botolph or Boltolphstone, was regarded for commercial purposes as an outpost for Lincoln until 1369 , when it became a staple town for wool, leather, etc., and its traffic and wealth increased greatly. Wines from Bordeaux were a regular feature of Boston's traffic. In 1317 to meet the expenses of the war against the Scots, collectors of ports were ordered to collect additional taxes on wines and spices.

$\dagger$ Douet-d'Arcq., L. Comptes de l'Argenterie des Rois de France au XIV' siècle, p. $253 . \quad$ † Ibid.

$\S$ The MSS. (Bibliotheque Nationale, Paris, Fonds Français 11205 , ancien 98-25) consists of 86 sheets of paper, quarto, several of which are blank, and the writing is in a neat hand, with numerous marginal notes. The relatively modern binding of stamped calf is lettered on the spine: rouRNAL DE RECET' ET DEPEN' DU ROY IRAN and Douet-d'Arcq thinks it English. He questions whether Brequigny, the antiquary who came to England at the end of the eighteenth century for the purpose of discovering historical documents of interest to France, may not have been responsible for bringing it to France (p. 194).
} 


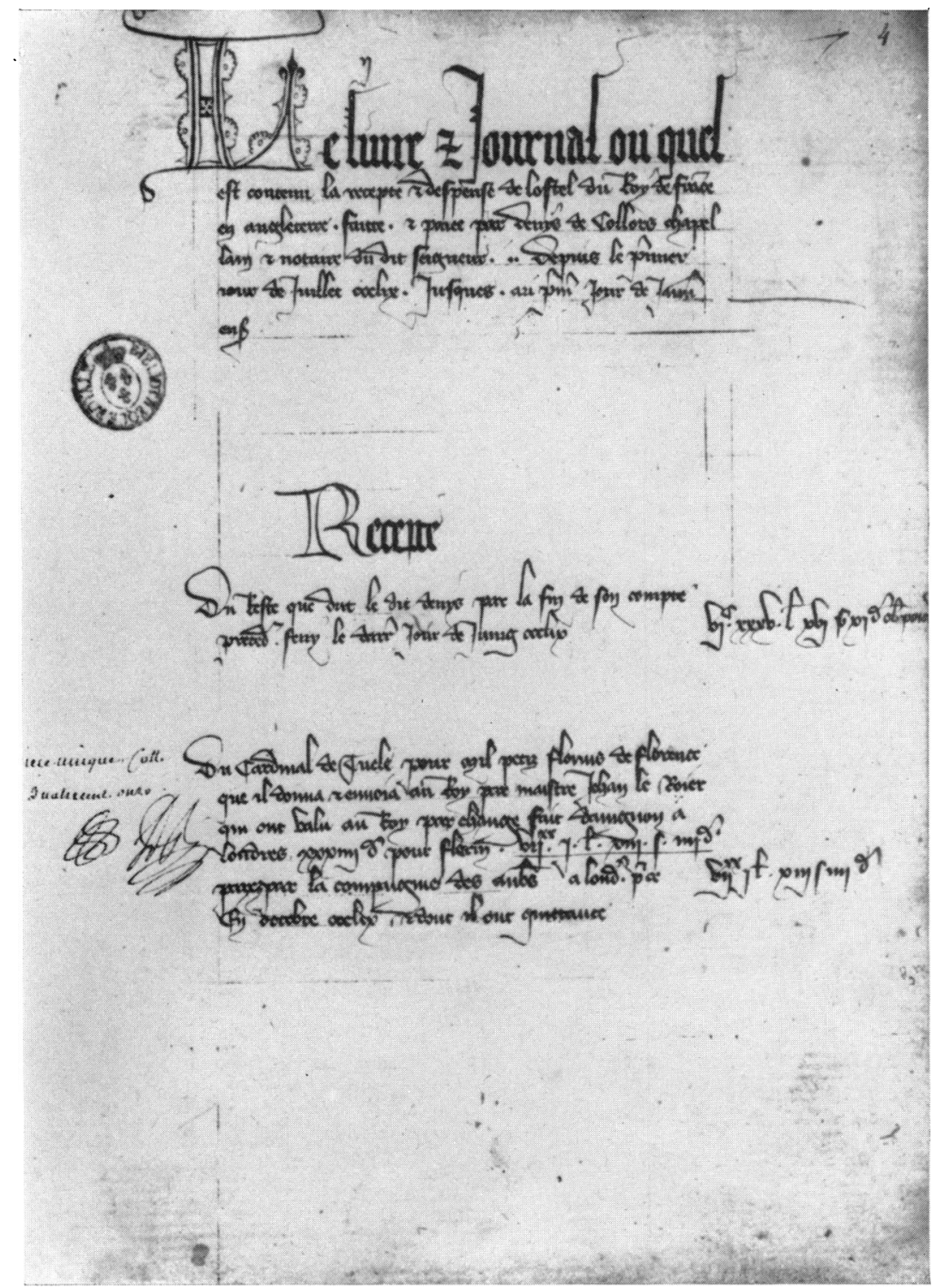

Fig. I

Journal de la Dépense du Roi Jean (fol. 4) Fonds Français I I205, Bibliothèque Nationale, Paris 


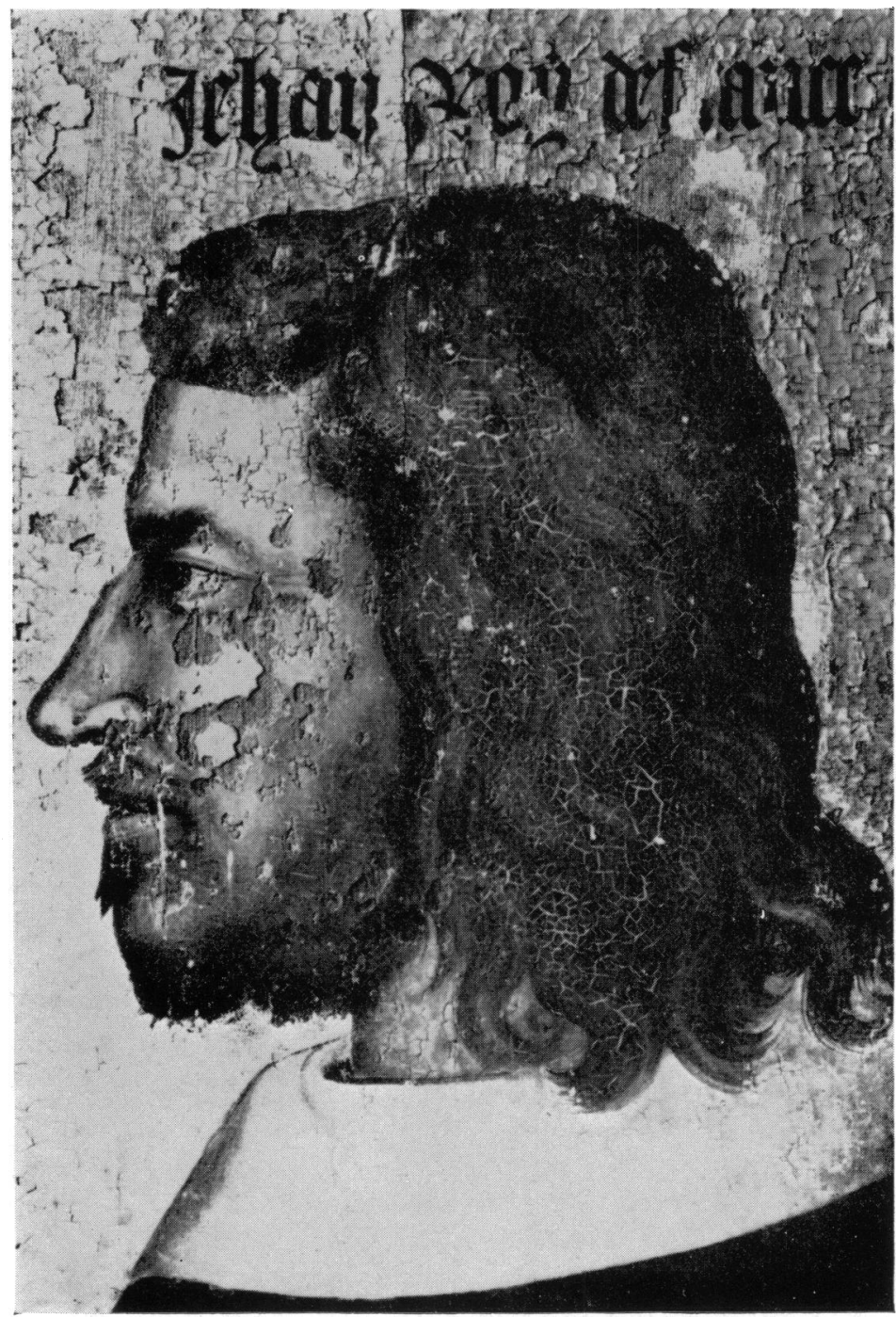

Fig. 2

Portrait of King John II of France, (?) Gerard d'Orleans, circa I 359 (French School, fourteenth century) Louvre, Paris, 
mixtures of about equal parts of sugar and highly prized (and praised) spices in the form of coarse powders and were in daily use at the royal table.*

John's household of something like forty persons for a large part of the time proved a good customer to the spicers. The first entry of note (Accounts, p. 206) is for $16 \mathrm{lbs}$ of sugar 'en pain' at $17 \mathrm{~d} \mathrm{lb;} 25 \mathrm{lbs}$ broken pieces of sugar at $15 \mathrm{~d}$ $\mathrm{lb}$; followed by a pound of powdered ginger I2d; $3 \mathrm{lbs}$ of green anise at $15 \mathrm{~d}$; $\frac{1}{2}$ pound of mace at $18 \mathrm{~d} ; \frac{1}{2} \mathrm{lb}$ of cinnamon $5 \mathrm{~s} ; \frac{1}{2}$ of cloves at $\mathrm{I} 7 \mathrm{~d} ; 4 \mathrm{lbs}$ of citron conserve I2s; oil of laurel $\frac{1}{4} \mathrm{lb}, 2 \mathrm{~d} ; \frac{1}{4}$ turpentine at $2 \mathrm{~d}$; total $76 / 5 \mathrm{~d}$. This purchase is entered on Friday 5 July 1359 and was made from Michael Girart, probably of London, by Jehannin de la Londe, the King's own espicier, described as of the 'Chambre'. He had varied duties, buying eggs to clarify sugar, presumably to make his white sugar-coated dragées, aromatic, carminative, or digestive, with anise, ginger or cinnamon. (Mention is made in June 1360 , of another royal espicier-Thomassin.)

Drugs and spices-for list see Table I-were mainly supplied by Pierre de Belle Assise (Peter Belassise), described as spicer of Lincoln; John Kelleshulle, spicer of St. Botolph (Boston); John Donat and Bartholomew Mine (or Myne), both spicers, of London, and Michael Girart-for notes on these see Appendix I.

As to sources of supply, the trade in drugs and spices, so far as England was concerned, was largely in the hands of the Flemish, Lombard and Hanseatic merchants. There were many established trade routes through Europe, from Egypt, the Levant and further East. The spice and drug trade had been cultivated by the Venetians ('when they-the Venetian Merchants-come to Pavia each of them is obligated to give to the Master of the Treasury every year (c. 1020) one pound of pepper, cinnamon, galanga and ginger') $\dagger$ and another well-established route is shown by the export tolls levied for the Duke of Savoy upon merchants of Milan wishing to sell their spices at the Geneva Fairs $(1433 / 4) . \ddagger$ The sea route via Narbourne was equally well-known in the thirteenth century.§ Pegolotti's 'List of 288 spices' $T$ (Florence, between 1310 and I340) includes practically all those purchased for King John.

The practice of medicine in France at the period, and hence prescriptions of Master G. Racine, the King's physician, would have been influenced by the current Formularies and Antidotaria. Those in use at the beginning of the fourteenth century are listed by Haefliger.** Urdang is of opinion that the number of Florentine apothecaries living in Avignon in the thirteenth and fourteenth centuries during the Papal schism exercised a great influence upon French pharmacy. $\dagger \dagger$

The Accounts record few prescriptions for personal ills, either for the King or his staff. On 26 June 1359 Thomas (l'appothecaire de Lincole) prepared an electuary for the King and a 'recette' was made up for him in London during April I 360 , at a cost of $2 s$. A julep ('gilop') and plaster, costing I2s. I Id., were prepared for Master Jean 'le Fol' who had come over with his Royal master

* Urdang, George. Introduction to the Pharm. Lond. (fascimile reprint), Madison, I944, p. I I.

$\dagger$ Lopez and Raymond. Medieval Trade in the Mediterranean World, London, 1955, p. 58.

$\$$ Ibid., p. 137 . 1 Ibid., p. 131.

* Cited by Urdang, op. cit., pp. 7-8. TI Ibid., pp. 108-1 14. $\dagger+$ Ibid., p. 13. 


\section{Leslie G. Matthews}

and who was a great favourite, judging by the many and frequent presents he received.* An apothecary charged 2 Is. $5 d$. for a visit to two of the household ill in London in June 1360 and a physician received $48 s .8 d$. for looking after Pioche, 'bariller du Roy'. $\dagger$

It is recorded that the spices and drugs were specially stored: this would be both on account of their nature, to avoid decomposition and mould as well as to retain the pungent aromatic odours so greatly appreciated, and possibly, to prevent theft, the commodities being readily saleable. That may be the reason why the purchase of locks for the spice boxes was essential.

Special 'dragouers', containers for the dragées, were noted in inventories of movables belonging to the King and in the private rooms of the royal family, and these were often in silver, silver gilt or jewelled. A dragouer had to be repaired in Lincoln. $\neq$

Boxes, specially made for the transport of spices ('panniers d'espices') were noted, costing $\ell_{2}$ each, as well as bags and canvas for wrapping purchases. Spice boxes, described as 'coffins' or 'escrins' were renewed from time to time. Frequently the spicer charged for wrapping paper-2d. a quire. On one occasion a horse and cart was hired specially to convey a particularly large quantity from Boston to Somerton Castle, 3/4d. being paid to the 'Tavernier' for his services.

While the total quantities of both drugs and spices, notably sugar, may seem excessive (see Table I), the number of the King's retinue was large and the King may have entertained the local gentry. He was noted for his many gifts to religious orders, all duly recorded by de Collors, and he was on friendly terms with the priest at Boothby, near Somerton. At Christmas, too, his retainers received presents: Maistre G. Racine, the royal physician, had 50 escuz, value $£ 86 s$. 8d., de Collors $£_{6}$ i $3 s$. $4 d$. and Jehannin the spicer $£ 36$ s. $8 d$. -others in proportion to their standing or duties. The King had made the offering (1359) of gold-moutons d'or, at the Christmas Mass, and at Epiphany (1360) presented the customary myrrh. (On Maundy Thursday he followed the long established French Royal Maundy custom of washing the feet of thirteen poor persons, each of whom received a penny.)

The accounts provide many illustrations of housekeeping of the period. Garments had frequently to be cleaned, and the more fragile were wrapped in a linen bag, worked in a bath of lye, for which on one occasion Aymonnet, the barber, provided the linen. A method of cleansing in some ways antedating the ubiquitous usage in France of Eau de Javel.

When the time came on 21 March 1360 for the King's removal to London (to the Tower, most of his retinue being lodged elsewhere) whilst the treaty of Brétigny was being discussed he had little idea, apparently, of the date of his release, for shortly after his arrival he authorized his Marshal to buy seeds 'for

* Accounts, op. cit., pp. 245-6.

† Ibid., p. 254

† Comptes de l'Argenterie, p. 216. On the handing over by Estienne de la Fontaine, Treasurer in 1353 , to his successor, Gaucher de Vannes, the inventory included-'un dragouer d'argent aे couvercle doré et esmaillé', another of similar make with a silvered crystal spoon, a third of polished stone ware, with a jewelled cover, and yet a fourth jewelled, 'semi d'esmaux'. (Comptes de l'Argenterie, p. 331.) 


\section{King Fohn of France and the English Spicers}

the garden of the house where his people were lodged'-onion, parsley, cabbage, borage, lettuce, beet, hysop, cress . . . and many others' at a cost of I Is., the gardener receiving $22 s . *$

Prior to his departure from London there were exchanges of courtesy between Edward III, his Queen, Eleanor of Hainault, and King John; these courtesies included dinners and presents. John left London on 30 June 1360 for Dover, via Rochester and Canterbury and arrived at Calais $8 \mathrm{July}$. There he had to remain as prisoner, however, until the first portion of the ransom, noted above, was paid. The peace between England and France was solemnly ratified by the two kings at Calais on 24 October 1360, when John, glad to be with his own people once more, left for Boulogne. $\dagger$

TABLE I

PURGHASES 1359-60 AND COMPARATIVE PRICES

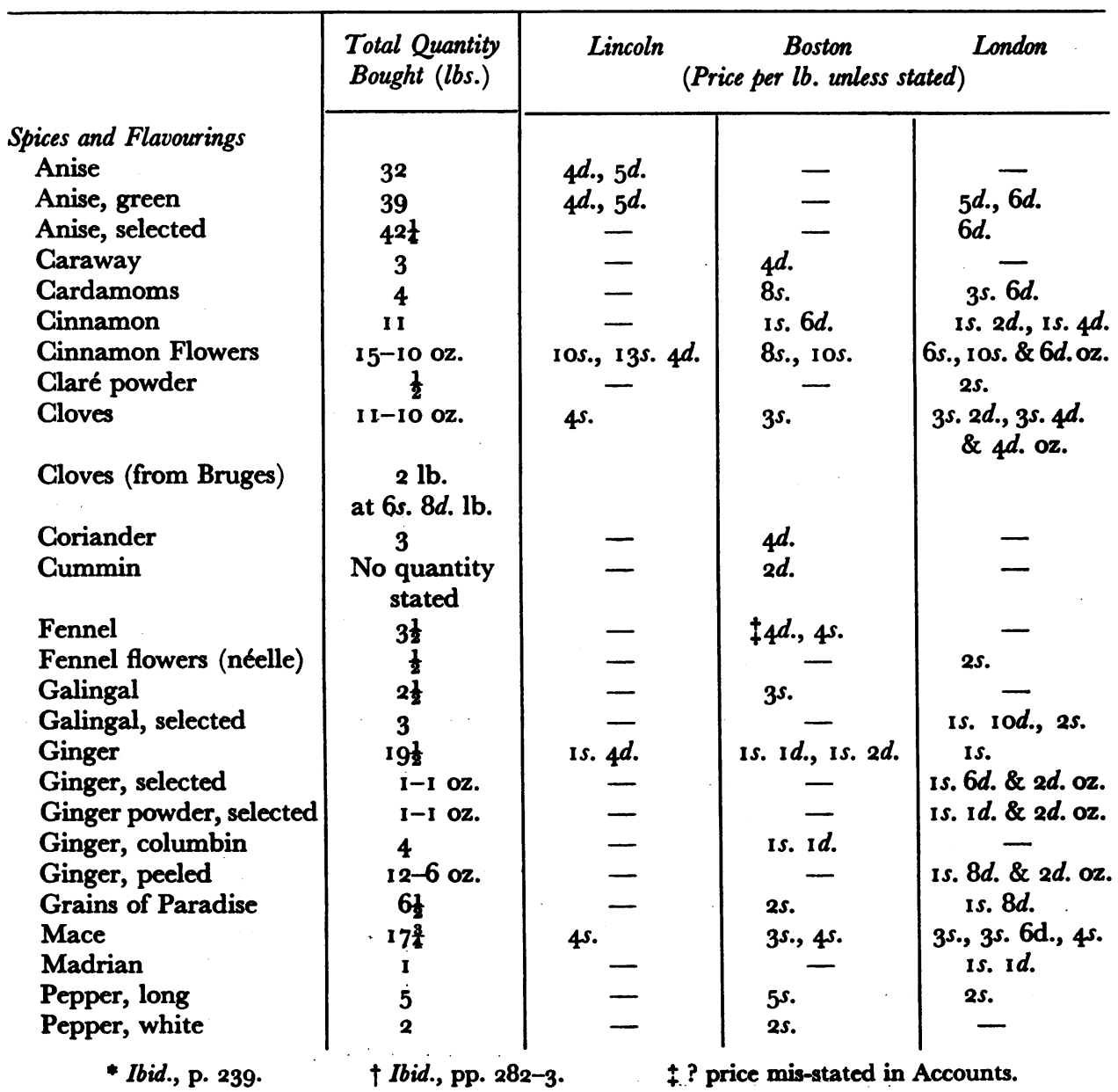


Leslie G. Matthewos

TABLE I-continued

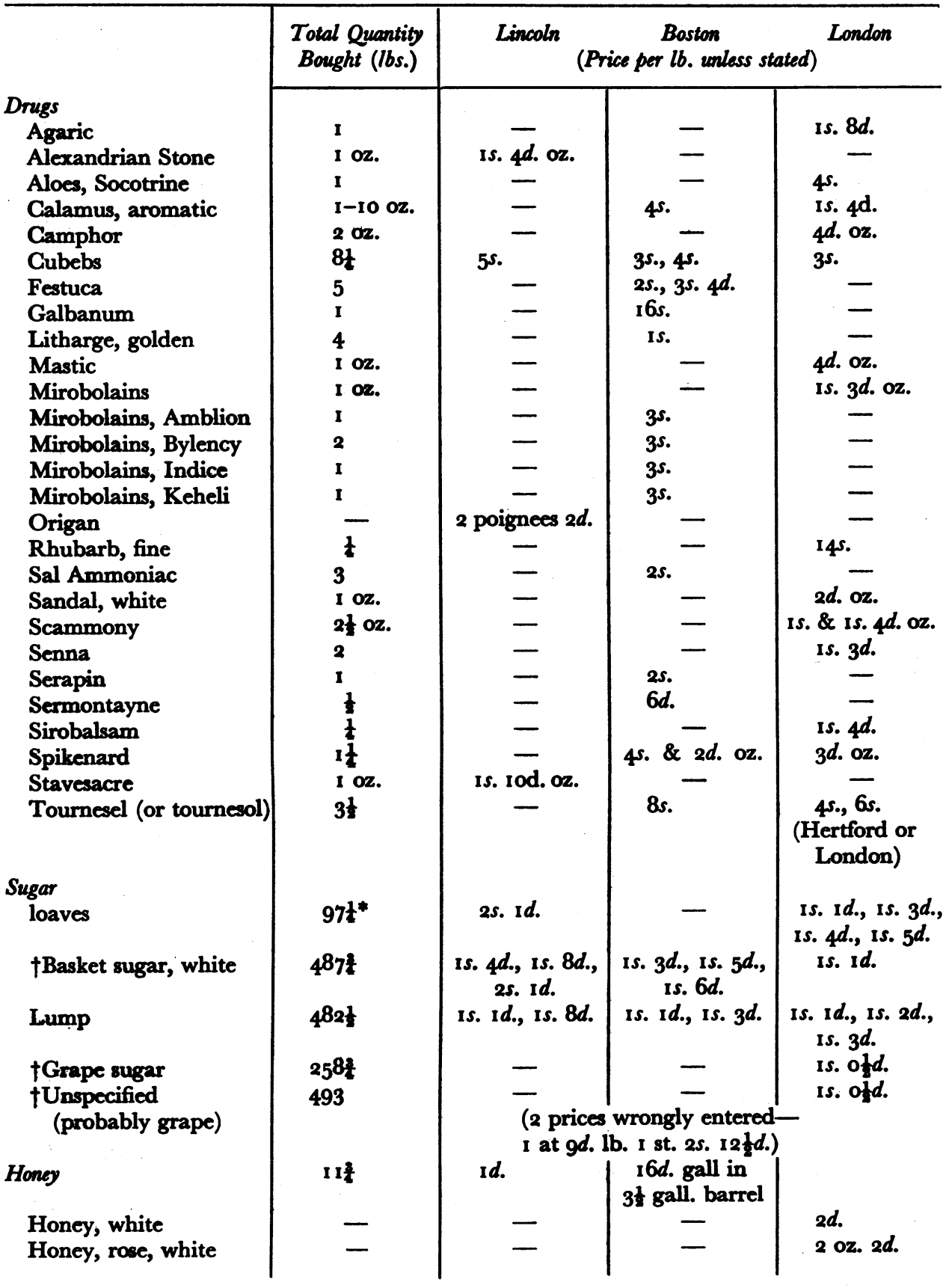

- Includes If lbs. (45.) bought from Thomas Vare, probably of Stamford.

t Heavy purchases June 1360 in London. 
King John of France and the English Spicers

TABLE I-continued

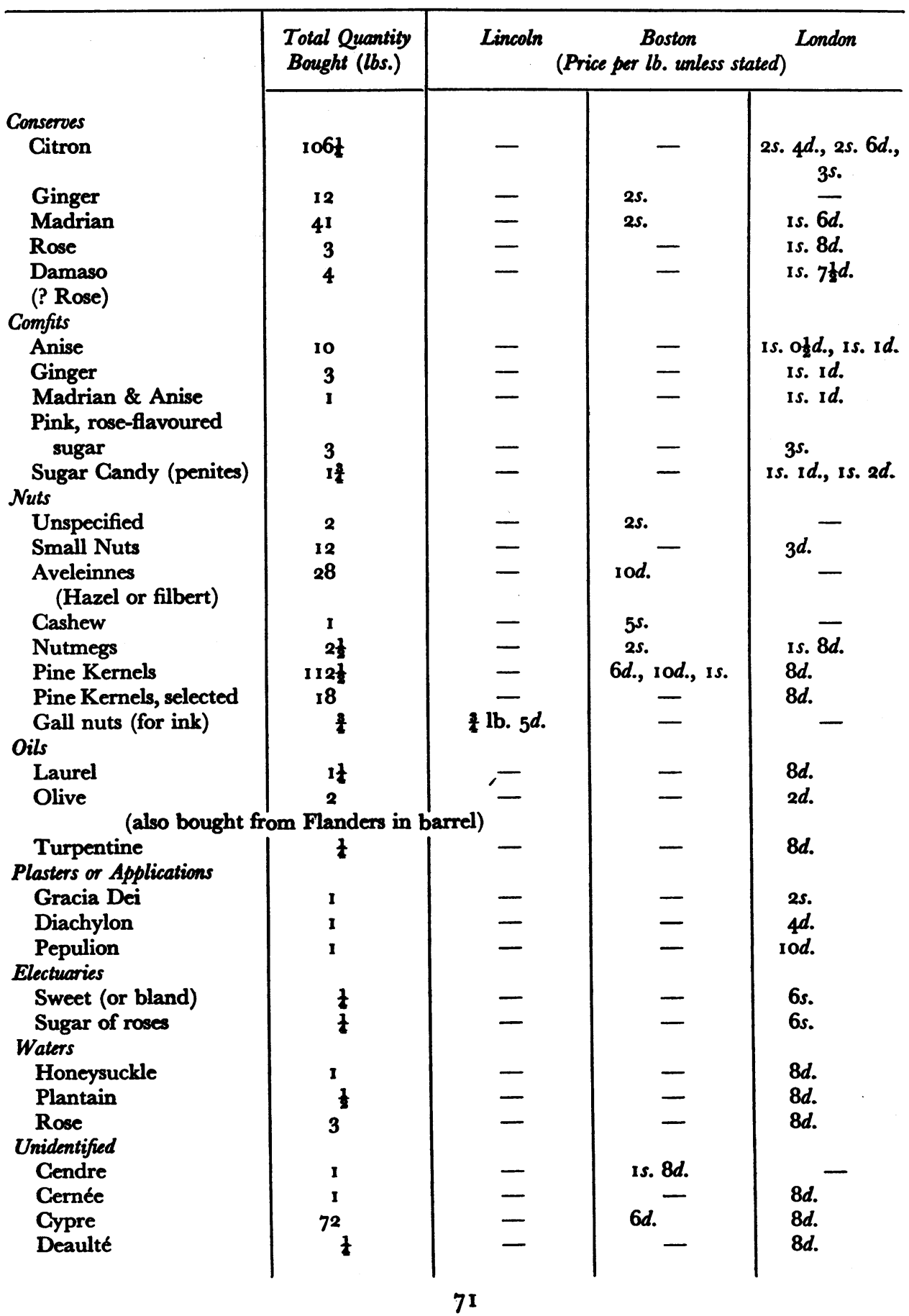


TABLE I-continued

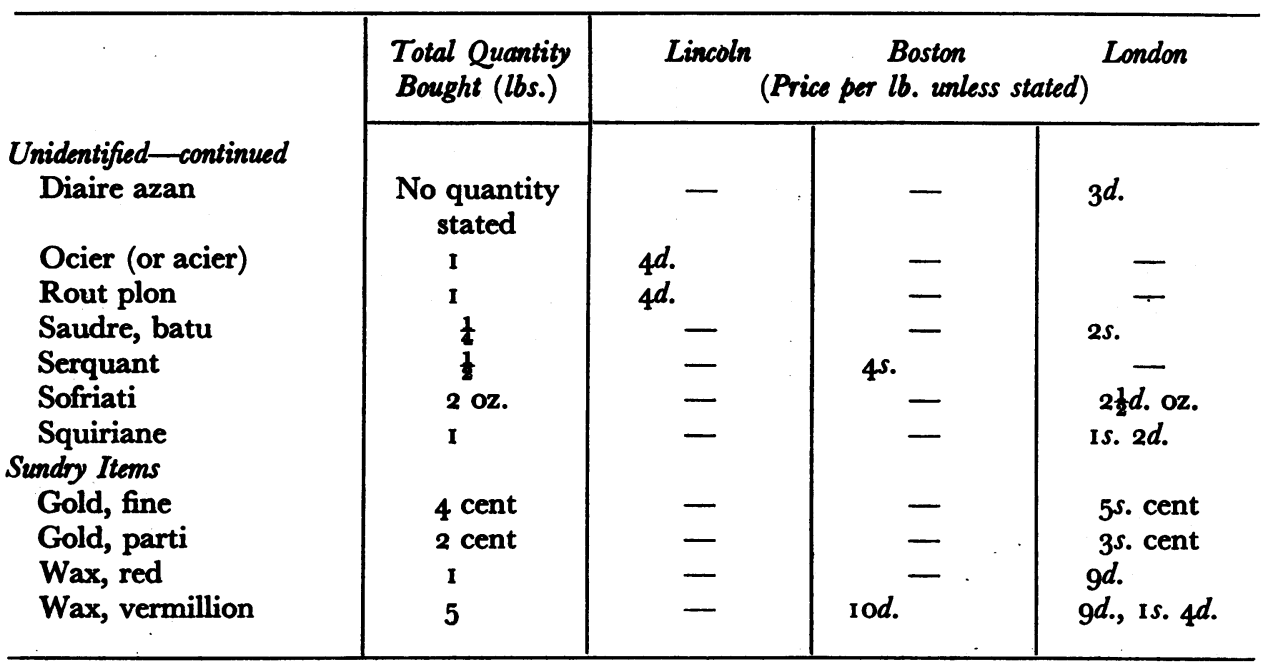

APPENDIXI

NOTES ON THE MORE UNUSUAL DRUGS AND SPICES MENTIONED

Taken from the glossary (mots techniques) given by Douet-d'Arcq, from Pomet's Histoire Gentrale des Drogues, Paris, 1735 , which he used, or from sourçes indicated.

Anise: 'One of the oldest of medicines and spices, known to Dioscorides and Pliny.' From Asia Minor, Greece or Egypt. H. G. Greenish, Materia Medica, 3rd ed. 1920, 11 9-120.

Cardamoms: Several varieties purchased: agreeable, aromatic. From India and Ceylon. Ibid., 138. Aloes, socotrine: The best variety (Pomet). Mixed with cinnamon, spikenard, xylobalsam (sirobalsam in the Comptes de l'Argenterie), mastic, asarum, saffron, and honey constituted the Hiera of Galen. Modifications in the formula were made on its introduction into the Pharm. Lond. 1618 and subsequently. Discontinued when the British Pharmacopoeia 1864 appeared. A. C. Wootton, Chronicles of Pharmacy, London, 1910, II, 140.

John D. Comrie (History of Scottish Medicine, London, 1932, 1, 62) mentions the use of an ointment of 'cicotrine' aloes in 1306-7 by Master Nicolas de Tyngewyk, physician to Edward I, as an application for the legs. The same accounts, quoted by Comrie (B. M. Add. MS. 25459), record the use of various plasters, turpentine, oil of laurel, etc. 'Many of these seem to be designed for the relief of cramps and colic.'

Coriander Seeds: Used as a carminative. 'The Confoctioners, after they have prepared the seeds with vinegar, cover 'em with sugar, which they call Coriander-Confects' (Pomet).

Ginger: A favourite flavouring bought in large quantities as conserve, in powder or root. The requirements for a wedding feast described in Le Menagier de Paris $c$. 1393 for 20 persons list quantities of spices almost identical with some of the orders placed with the Boston spicers-colombine ginger, cinnamon, ground rice, sugar, saffron, cloves, grains of Paradise, long pepper, galingale, mace, candied orange peel, citrin, rosewater, white comfits, etc. (The Paris prices quoted, however, are eight to ten times those paid in Boston.) Eileen Power, The Goodman of Paris, London, 1928, 241. 


\section{King John of France and the English Spicers}

Grains of Paradise: Guinea grains-seeds of Amomum malagueta. From West Africa, via Tripoli. 'Much esteemed as a spice in 12 and 13 Genturies.' Greenish, op. cit., 185.

Madrian: All references so far traceable derive from the Comptes de l'Argenterie and describe madrian as a kind of fruit or spice. (Fr. Godefroy in Dictionnaire de L'Ancienne Langue Frangaise, Paris, 1888, vol. v, 64 quotes E. Deschamps Poes. Richel 840 fo $497^{\text {e. 'Paste }}$ du roy bien arrangée Annis, madrian, noix confites'.)

Agaric Fungus from White fir trees (Abietis). Anec. Oxon, Oxford 1882; Sinonoma Bartholomei (S.B.) 12.

Alexandria Stone: Tutty powder-impure oxide of zinc. Used in ointments. Wootton, op. cit., $\mathbf{I}$, I59.

Calamus Aromatica: Sweet flag rhizome.

Cendre: Probably wood ash.

Cubebs: Fruit of Piper cubeba: used as spice and medicine in Middle Ages. Diuretic and antiseptic. 'Of admirable use to make the breath sweet' (Pomet). Greenish, op. cit., 1 29-132.

Galbanum: Gum resin in tears or lumps. From Persia or Levant. Used as stimulant in plasters.

Fennel Flower (Néelle): Nigella Romaine seed; highly aromatic. Mainly used in preparation of Theriaca (Pomet).

Galingal: Spice, and also used (in Russia up to 1920 ) as stimulant, and carminative for flatulent dyspepsia. Greenish, op. cit., 381.

Litharge, golden: Yellow oxide of lead: used in ointments or plasters.

Mirobolains: Purgative berries from India, several varieties.

Origan: Dittany: reputedly for wounds. Iapyx, taught by Apollo, treated Aeneas with Dittany. Quoted by Wootton, op. cit., , 26.

Sandal, white: Yellow sandal wood of commerce. Used in form of powder or oil as stimulant in genito-urinary tract. From S. India. Greenish, op. cit., 231.

Serapin (or Serapium): Synonym sometimes used for sinapis (mustard). S.B., op. cit., 39. Name also used for syrup of roses (Gerarde). Anec. Oxon. (Alphita) 166, i53.

Sermontayne: Syrmontane (or serapium) Siler montanum-willow. Alphita, op. cit., 169.

Sirobalsam: See note under Aloes-Gum from branches of the Balsam shrub, shipped through Cairo to Marseilles (Pomet). Resinous and aromatic, used for Troches.

Spikenard: Bought by the ounce. The nardostochys of Dioscorides and Galen. Probably imported in paste or as oil from India. Wootton, op. cit., 1, 73-4.

Stavesacre: Seeds used in ointment or paste for headlice.

\section{UNIDENTIFIED}

Cernée: (?) cina: wormwood, anthelmintic.

Cypre: Diaire azan: (?) dia resin: mixed resins.

Cypre:

Diaire azan: (?) dia resin: mixed resins. S.B., op. cit., 36.

Ocier (or acier): (?) acer herb. S.B., op. cit., 9.

rout plon: (?) ruta pollen (powdered rue). Alphita, op. cit., $157-8$.

Saudre batu: (?) alysaundre: used as herb for pottage. Eileen Power, op. cit., 24 (from B.M.m.s. Sloane 1201).

Squirine: (?) Jequirity seeds: India.

Tournesol (or Tournesel): Name applied to varieties of Helianthus or sunflower. Paste, moist or crumb, made from seed. Blue-violet in colour. Also used by dyers (Pomet).

Conserve: Strictly, consisted of only one medicament and sugar. Wootton, op. cit., II, 285.

Penites (or penices): O. E. Penydes-Sugar candy-a thread around which sugar has been allowed to crystallize. 'A little wreath of sugar taken in a cold.' S.B., op. cit., 139 .

Gold: Used in medicine from the days of Avicenna. Possibly here for gilding of pills or as an ingredient of them. 


\section{Leslie G. Matthews}

Plantain Water: Used as salve or lotion. For a broken skin called for by Costard-Love's Labour Lost, Act III, Sc. I, 'Plantain, a plain plantain; no salve sir, but a plantain'. Quoted by Wootton, op. cit., $\mathrm{I}, 74$.

Plasters or Applications: Diachylon Plaster. Lead plaster, said to have been invented by Menecrates, Physician to Tiberius. A complicated formula was devised by Mesuë. Wootton, op. cit., 1,91 , and $\mathrm{II}, 128$.

Populeon: Populeum, 'An ointment made from the buds of the black poplar, prescribed by Nicolas of Salerno as a narcotic and resolvent application'. Ibid., n, 298.

Gracia Dei Plaster: Plaster containing tar (picis). Ibid., $\mathbf{n}, 285$.

\section{APPENDIX II}

\section{NOTES ON THE SPICERS MENTIONED IN THE TEXT}

BeLLe Assise (or Belassise) PETER, LINCOLN. A man of substance and probably a member of the Lincoln Gild of St. Mary's, since in 1363 (4 years after the date of these accounts) Peter Belassise and John Blyth of Lincoln had 'licence to alienate (to the Gild) a messuage in Lincoln to two Chaplains as before', i.e. in St. Andrew's Church, 'to celebrate for the graceman, brothers and sisters of the ancient Gild of St. Mary and for the Soul of King Henry III, a former brother of the Gild' (J. W. F. Hill, Medieval Lincoln, Cambridge, 1948, p. 165).

Donat, John, London. A Lombard merchant, entered as of the Grocers Company, r373.* Clothed with Livery of Grocers, $1383 . \dagger$

Was subjected to an inquiry by wax chandlers before the Mayor and Aldermen whether or not a certain torch made in his house was justly made. Decision was that it was made to deceive and was a scandal in the City. Fined $20 s$. in lieu of prison. $\ddagger$ 3rd April 1358.

John, with his brother Nicholas, a spicer (and Bartholomew Mine-see below), were described as of Lombard Street and were called as part of a Jury (one half citizens, one half Lombards) at a plea held before John Pecche, Mayor, and others. Non-appearance of the Jury recorded.§ Roll. A.8 p. 259. 3rd October 1362. Surety (with Bartholomew Mine), each in sum of $£ \mathrm{I}, 000$, to produce Thomas Serlendi, Merchant of Lucca, for trial. $\mid$

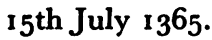

Lease executed by Walter de Chesthunt in favour of John Donat, spicer, of houses in Bokeleresbury (Bucklersbury) in the parish of St. Stephen, Walbrook, for 21 years at annual rent of 20 marks. (Bartholomew Mine was a witness.)** 16 th Nov. 1366 .

Auditor and main pernor in action against certain Lombards. $\dagger \dagger 5^{\text {th }}$ July 1369 .

Surety for Thomas Serland and one of a number of Lombards who proved rent for a house had been paid. $+\ddagger 25$ th September 1371 .

Concerned in 2 merchant cases in one of which he is described as a merchant of Sienna. $\S$ 137 I.

Lodevic Poule de Florence admitted a broker in City of London. Sureties: John Donat ('grocer') and Bartholomew Myne.** I3th October 1373.

Mentioned as a Legatee in the will of Walter (son of Sir Walter de Chesthunt, Knt.). $\mid$ 23rd Oct. 1376.

Described as citizen and apothecary (he was then of the grocers) and as having written

* Grocers Company, Part I, facsimile, London, 1886, p. 45.

¥ Calendar of Letter Books of the City of London $(G), p_{.} 92$.

8 Calendar of Plea \& Memoranda Rolls of the City of London $1323-1364$. Cambridge, 1926.

If Ibid., p. 39.

t† Pleas, op. cit., pp. $110-11$. $\quad$ ¥ Ibid., p. 131 .

$\$ \S$ Ibid., Pp. 278-9.

ปा Cal. of Wills, Court of Hust., 1x, Ir, London, 1890, p. 229. 


\section{King Fohn of France and the English Spicers}

a letter of Attorney to Guynus Bartholomei, Merchant of Sienna.* 2nd September 1391. Died 1391 or 1392.

Plea in Chamber of Guildhall, according to Law merchant and custom of City, against his son Nicholas and a clerk, administrators of the goods of J. D. (late citizen and merchant): J. D. had charge of certain jewels pledged against a loan owing by Duke de Berry to the plaintiff. If loan paid J. D. to keep the jewels held. Finally settled that Amy, wife of deceased, keep the jewels. $\dagger$ I4th May 1392.

girart, michael. Probably Michael Gerard, of London. Purchases were made from him by the King's Spicer who had frequent contact with London when he was with the King at Hertford. Lombard merchants were much engaged in the London spice trade at that period-see below. Under the Will of Thomas Blundel, Rector of the Church of St. Stephen, Walbrook, lands, tenements, etc. in 'Lumbardestret' were left to Cecilia, wife of Michael Gerard, 'Lumbard', Citizen of London. $\ddagger$ 8th April 136r.

A Michael Gerard is recorded as having entered into a bond in the Gity of London, prior to 27 th April $1362 . \S$ Hugelyn Gerard, possibly a younger man of the family, was one of a number of foreign merchants, including Lombards, who represented that conditions relating to the garbelling of spices and the polishing of wax be applied fairly as between themselves and other London merchants. I

kelleshulle, John, Boston. The name suggests Danish, Flemish or German origin. Pishey Thompson (History and Antiquities of Boston, Boston, 1856, p. 42) says that in the thirteenth century 'the Hanseatic merchants and those of Flanders carried on at this time a very large and important traffic in Boston'. Many of the names current in Boston in the fourteenth century were Danish. The name Kelleshulle is not amongst the many cited by Thompson as members of the principal Gilds, though Wills of Gerard Heshull and Robert Hulle (mid-fifteenth century) have been published by Foster. Shop rents were not dear by the standards of taxation at the time. In 1334 a piece of land and a shop was let for $2 s$. a year.

mine (or Myne), bartholomew, london. Admitted to Grocers Company. Fine i2d. paid on his behalf by Vyugen Roger. 22nd October $13490^{* *}$

Died (?1373) - under entry 'of the Fraternity of Grocers' marked 'mortuus est'. Christmas $1373 . \dagger \dagger$

A Lombard merchant, closely associated with other Lombards and particularly with John Donat-see note above.

With William de Enyesham, B.M. was concerned in an action for debt against John Poul of Pistoya. 4th April 1365. $\ddagger$

Described as 'spicer' and entered into a mainprize for William Gifford, to observe the King's peace. 20th June 1368 .\$\$ Was one of 4 sureties in guardianship of Stephen, son of

RICHARd ATTE 'HALLe' committed by the Mayor, Aldermen and Chamberlain to Andrew de 'Oo' (or Hoo). ist March $1368-9$.

Was one of the citizens who lent money (B.M. lent £30) to King Edward III, payment of the loan being authorized out of customs on wool, leather, etc., exported from the port of London. Ist Feb. 1370-1.***

SPAIGNE, G., BOstoN. The Spaignes or Spaynes were an old established Lincolnshire family, early connected with the Trading Gilds in Boston. William de Spayne was a member of the Gild of Corpus Christi, Boston, in 1342 (Pishey Thompson, History and Antiquities of Boston, Boston, 1856, p. 116 ) and Mayor of the Lincoln \& Boston Staple for 3 periods 1353-63. (J. W. F. Hill., Med. Lincoln, Cambridge, 1948.) Robert de Spayne was an

- Calendar of Letter Books of the City of London (G), p. 174.

$\$$ Cal. of Wills, op. cit., 11, Roll. go-70.

8 Calendar of Letter Books of the City of London $(G)$, p. 135.

* Grocers Company, Part I, facsimile, London, I886, p. 35.

¥ Calendar of Plea $\mathcal{E}$ Memoranda Rolls of the City of London, 1323-1364, p. 31 .

ขึ Calendar of Letter Books of the City of London $(G)$, p. 239.

† Pleas, op. cit., nI, pp. 185-7.

TI Ibid.

†† Ibid., p. 45 .

$\$ \$$ Ibid., p. 89.

*** Ibid., p. 276. 


\section{Leslie G. Matthews}

Alderman of Boston in 1349 and 1356 (Thompson, op. cit.). Spain Lane and Spain Court, with some 'ancient buildings' are mentioned by Thompson (op. cit., p. 232). In the rental of the Gild of Corpus Christi, Boston, 1439, mention is made of 6 acres of pasture called Spycer Green (p. 129).

VARE, тномAs, probably of Stamford, Lincs. Sugar was bought from him when the King stayed one night at Stamford on his way from Hertford to Somerton Castle. 